\title{
Intestinal parasites in cancer patients in the South of Brazil
}

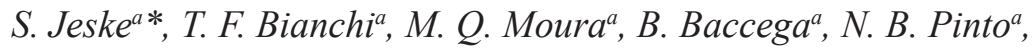 \\ M. E. A. Berne and M. M. Villela ${ }^{a}$ \\ aPrograma de Pós-graduação em Parasitologia, Departamento de Microbiologia e Parasitologia, \\ Instituto de Biologia, Universidade Federal de Pelotas - UFPel, Capão do Leão, s/n, \\ CEP 96010-900, Pelotas, RS, Brazil \\ *e-mail: sabrinajeske@hotmail.com
}

Received: February 3, 2017 - Accepted: April 25, 2017 - Distributed: October 31, 2018

\begin{abstract}
Intestinal parasitic infections in immunocompromised patients can lead to serious complications when not diagnosed and treated early. This study aimed to investigate the frequency of intestinal parasites in cancer patients undergoing chemotherapy in the South of Brazil. Three fecal samples collected from each patient (73 individuals) were processed by Ritchie and Faust techniques and submitted to specific staining methods for intestinal protozoa. A 61.6\% parasite and/or commensal positivity was found. Helminths identified were Ascaris lumbricoides (33.3\%), Taenia spp. (6.6\%), Strongyloides stercoralis (4.4\%) and Trichuris trichiura (2.2\%). Among protozoans, Giardia lamblia (26.6\%), Cryptosporidium spp. (13.3\%) and Cystoisospora belli (4.4\%) were identified. The presence of Entamoeba coli, Endolimax nana and Entamoeba hartmanni was also recorded. The results obtained warn of the importance of fecal parasitological diagnosis and the use of specific staining methods for the detection of intestinal parasites in cancer patients. These exams should be regularly requested at the patient's first clinic visit, given the high prevalence found in this study and the possible severity of such conditions for these individuals.
\end{abstract}

Keywords: intestinal parasites, immunocompromised patients, cancer.

\section{Parasitos intestinais em pacientes com câncer do Sul do Brasil}

\section{Resumo}

As parasitoses intestinais em pacientes imunocomprometidos podem levar a graves complicações se não diagnosticadas e tratadas precocemente. Este estudo teve como objetivo investigar a frequência de parasitos intestinais em pacientes oncológicos submetidos ao tratamento quimioterápico. Foram coletadas três amostras de fezes de cada paciente, sendo processadas pelas técnicas de Ritchie e Faust e submetidas à métodos de coloração específicos para protozoários intestinais. Foi encontrada positividade de 61,6\% para parasitos e/ou comensais. Os helmintos identificados foram Ascaris lumbricoides (33,3\%), Taenia spp. (6,6\%), Strongyloides stercoralis (4,4\%) e Trichuris trichiura (2,2\%). Dentre os protozoários, foram identificados Giardia lamblia (26,6\%), Cryptosporidium spp. (13,3\%) e Cystoisospora belli (4,4\%). Também foi registrada presença de Entamoeba coli, Endolimax nana e Entamoeba hartmanni. Os resultados encontrados alertam para a importância do diagnóstico parasitológico de fezes junto à utilização de colorações específicas para parasitos intestinais em pacientes oncológicos, sendo que os mesmos deveriam ser requeridos como conduta já na primeira consulta clínica destes pacientes, dada à elevada prevalência aqui constatada e a possível severidade que tais moléstias podem acarretar nestes indivíduos.

Palavras-chave: parasitos intestinais, pacientes imunocomprometidos, câncer.

\section{Introduction}

Current estimates indicate that at least a quarter of the world's population, mostly in developing countries, is chronically infected with intestinal parasites (Alemu et al., 2011). Despite sanitation improvement and hygiene education in recent decades, these infections continue to be characterized as a major cause of morbidity worldwide (Lustigman et al., 2012). In immunocompromised individuals, such agents are recognized as important enteric pathogens, and may lead to fatal complications (Marcos and Gotuzzo, 2013).

Among intestinal parasites, Cryptosporidium spp. and Strongyloides stercoralis stand out for their opportunist character. These parasites can lead to serious complications in patients with immune deficiency. Cancer patients, in turn, become immunocompromised either as a result of 
the disease itself or due to therapeutic agents/procedures causing immunosuppression (Silva et al., 2011; INCA, 2016). For this reason, it is extremely important that prevalence and risk factors associated with parasitic infections be determined for this group (Utzinger et al., 2012).

Different groups of immunocompromised individuals have been studied regarding intestinal parasites; however, cancer patients are still poorly investigated. Such limitation of studies is harmful, since research of this nature could serve as the basis for adopting specific preventive measures to these patients, as well as providing new approaches to oncologists (Pacheco et al., 2014).Therefore, the aim of this study was to evaluate the frequency of intestinal parasites in cancer patients undergoing chemotherapy treatment in the South of Brazil.

\section{Methods}

\subsection{Place and study population}

This was a prevalence epidemiological study whose research subjects were cancer patients referred to chemotherapy in two specialized clinics in the city of Pelotas, located in southern Rio Grande do Sul (RS) State, south of Brazil. Is worth informing that Pelotas is a major county in southern RS, receiving patients from all over the South of the State, and that all neoplastic patients who attended both clinics in a 06 month period were invited to participate in the study.

\subsection{Data and fecal sample collection}

Data collection was started after an Informed Consent (IC) form was signed by each patient, who then answered a questionnaire aiming to outline their socioeconomic profile as well as identify other epidemiological characteristics. Along with the Informed Consent form, the patients were given an educational folder showing major intestinal parasites and ways to prevent them. After completing the questionnaire, the research participants were given three disposable bottles containing a duly identified MIF (merthiolate or mercury, iodine and formaldehyde) preservation solution. The collected material was taken to the Human Parasitology Laboratory of the Federal University of Pelotas for processing. This study was approved by the Ethics Committee under Protocol 502/589. All positive patients were referred to medical treatment.

\subsection{Processing and analysis of fecal samples}

The methods employed were macroscopic examination, Faust technique and Ritchie technique. Kinyoun staining for the detection of opportunistic intestinal coccidia was also used. After being processed, samples were analyzed under an optical microscope.

\subsection{Data statistical analysis}

For data analysis, an Excel 2007® software database was developed. The association between the results of fecal examinations and epidemiological variables identified in the questionnaire were weighed by the XIII Minitab statistical software version $\AA$ using the chi-square test, and those associations with $\mathrm{p} \leq 0.05$ were considered statistically significant.

\section{Results}

A total of 73 patients aged from 20 to 85 years from 15 different municipalities in southern Rio Grande do Sul (RS) State, Brazil, participated in the study. Of the patients surveyed, 45 (61.6\%) were positive for one or more species of intestinal parasites and/or commensals (Table 1). Among positive patients, $53.3 \%$ showed single and $46.7 \%$ multiple parasitic infections. The most frequent association was that of Ascaris lumbricoides and Giardia lamblia, which represented $23.8 \%$ of cases of multiple parasitic infections.

As for socioeconomic and environmental variables evaluated, as shown in Table 2, only having dogs and/or cats as pets showed a statistically significant association with positive cases of intestinal parasites in cancer patients $(\mathrm{p}=0.025)$.

The association between positive cases and the type of cancer was also evaluated, but there were no significant statistical differences. Breast cancer showed the highest occurrence (32/43.8\%), followed by intestinal $(10 / 13.7 \%)$ and stomach $(6 / 8.2 \%)$.

\section{Discussion}

According to the National Cancer Institute, eight million new cases of cancer are diagnosed each year worldwide, with an increase of almost $40 \%$ over the last 20 years (Inca, 2016). Cancer patients run a great risk of developing enteroparasitic infections, as they are more susceptible to opportunistic agents due to anticancer treatment and are already immunocompromised because of the disease itself (Vento and Cainelli, 2003). These opportunistic infections are usually more severe in this group of individuals, and may even lead to fatal complications (Marcos and Gotuzzo, 2013). Of the 73 participants in the study, 45 (61.6\%) were positive for one or more parasitic species, a similar index to that found in other studies, such as a $66.7 \%$ figure found in cancer patients in Brazil (Silva et al., 2011).

Table 1. Prevalence of intestinal parasites (pathogenic and commensal) and their frequencies in cancer patients from southern Brazil undergoing chemotherapy $(n=73)$.

\begin{tabular}{cc}
\hline Pathogenic parasites & $\mathbf{( \% )}$ \\
\hline Ascaris lumbricoides & 33.3 \\
Giardia lamblia & 26.6 \\
Cryptosporidium spp. & 13.3 \\
Taenia spp. & 6.6 \\
Strongyloides stercoralis & 4.4 \\
Cystoisospora belli & 4.4 \\
Trichuris trichiura & 2.2 \\
\hline Commensals parasites & $\mathbf{( \% )}$ \\
\hline Entamoeba coli & 31.1 \\
Endolimax nana & 26.6 \\
Entamoeba hartmanni & 4.4 \\
\hline
\end{tabular}


Table 2. Association between socioeconomic and environmental variables with positive cases for intestinal parasites in cancer patients from southern Brazil.

\begin{tabular}{|c|c|c|c|c|}
\hline \multirow{2}{*}{ Variables } & \multicolumn{4}{|c|}{ Positive patients $=45 / 73$} \\
\hline & Total & Positive & $\%$ & $\mathbf{p}$ \\
\hline Age & & & & 0.641 \\
\hline 20-50 years & 23 & 16 & 69.5 & \\
\hline $51-85$ years & 50 & 29 & 58 & \\
\hline Gender & & & & 0.387 \\
\hline Male & 17 & 12 & 70.6 & \\
\hline Female & 56 & 33 & 36.9 & \\
\hline Family income & & & & 0.499 \\
\hline $\begin{array}{l}\text { Until } 1 \\
\text { minimum wage* }\end{array}$ & 27 & 18 & 66.7 & \\
\hline $\begin{array}{l}\text { more than one } \\
\text { minimum wage* }\end{array}$ & 46 & 27 & 58.7 & \\
\hline Educational level & & & & 0.465 \\
\hline $\begin{array}{l}\text { Up to } \\
\text { elementary } \\
\text { school }\end{array}$ & 43 & 28 & 65.1 & \\
\hline $\begin{array}{l}\text { Beyond } \\
\text { elementary } \\
\text { school }\end{array}$ & 30 & 17 & 56.7 & \\
\hline Housing & & & & 0.163 \\
\hline Masonry & 70 & 42 & 60 & \\
\hline Wooden & 3 & 3 & 100 & \\
\hline Peridomiciliar area & & & & 0.448 \\
\hline Pavement & 35 & 20 & 57.1 & \\
\hline Others & 38 & 25 & 65.8 & \\
\hline Plumbing & & & & 0.695 \\
\hline Yes & 61 & 37 & 60.6 & \\
\hline No & 12 & 8 & 66.7 & \\
\hline Residing in area & & & & 0.508 \\
\hline Rural & 16 & 11 & 68.7 & \\
\hline Urban & 57 & 34 & 59.6 & \\
\hline Garbage disposal & & & & 0.387 \\
\hline Public collection & 56 & 33 & 58.9 & \\
\hline Others & 17 & 12 & 70.6 & \\
\hline Vegetable garden & & & & 0.101 \\
\hline Yes & 15 & 12 & 80 & \\
\hline No & 58 & 33 & 56.9 & \\
\hline Dog and cat as a pet & & & & 0.025 \\
\hline Yes & 48 & 34 & 70.8 & \\
\hline No & 25 & 11 & 44 & \\
\hline
\end{tabular}

*Minimum wage in Brazil $=\mathrm{R} \$ 788.00$ (approximately US \$ 250.00 in July 2015).

The most frequent parasite was Ascaris lumbricoides $(33.3 \%)$, which showed a much higher prevalence than that found in AIDS patients in Brazil (7.7\%) (Amancio et al., 2012). Infection by $A$. lumbricoides associated with other immunosuppressive diseases has been described in other studies and may be related to a wide prevalence of this helminth in humans around the world (Lau et al., 2007; Brum et al., 2013). It is worth mentioning that eggs of this helminth have been found in public parks within city limits, which is suggestive of a considerable risk of infection and its high prevalence among the local human population (Moura et al., 2013).

As for the protozoan Giardia lamblia, despite being most commonly found in children (Torres-Romero et al., 2014; Ferreira et al., 2015) it was diagnosed in $26.6 \%$ of patients in this investigation, in which the youngest infected individual was 20 years old. Its concomitant occurrence with cancer probably arises from a deficiency in the immune system of neoplastic individuals which causes an increased susceptibility to infections, since its occurrence is usually lower in adults due to the development of a certain degree of resistance (Silva et al., 2011). Although G. lamblia is not thought to be an opportunistic pathogen, the infection in immunocompromised patients may be more serious, with a marked proliferation of the parasite and, therefore, the worsening of his clinical condition (Cotton et al., 2011). G. lamblia prevalence was higher in this study as compared to that found in immunocompromised patients from other countries, such as $6.6 \%$ in immunocompromised patients in Saudi Arabia (Al-Megrin, 2010), and an 8.5\% prevalence in patients undergoing dialysis in Turkey (Karadag et al., 2013).

The $13.3 \%$ Cryptosporidium spp. frequency was similar to that found in HIV-positive patients referred to the UFTM hospital (MG), where a $10.1 \%$ rate was found (Assis et al., 2013). However, this coccidial infection showed an even higher prevalence in immunocompromised patients from other countries, such as 53\% in kidney transplant patients in Pakistan (Raja et al., 2014) and 43.6\% for HIV/AIDS patients in Ethiopia (Alemu et al., 2011). In addition, studies have linked Cryptosporidium spp., among other parasites, to the development of cancer, inasmuch as it is believed that chronic inflammation of the intestinal tract due to the presence of the parasite could induce pathological disorders with adenocarcinoma genesis. Studies have also shown that even low doses of this protozoan may induce gastrointestinal neoplasia (Benamrouz et al., 2014; Oliveira, 2014). Nevertheless, this relationship has not been diagnosed in this study. More specific studies on this association should be performed.

The 4.4\% Cystoisospora belli frequency in immunocompromised patients should be considered relevant, since this parasite can cause severe dehydration due to intense and prolonged diarrhea; less commonly, there may be extraintestinal dissemination, especially in immunosuppressed individuals (Resiere et al., 2003; Townsend and Cavuoti, 2015).

Strongyloides stercoralis occurrence (4.4\%) showed a lower frequency than expected, certainly due to the methods used, which were not specific for the diagnosis of this parasite. Its worldwide prevalence varies between 10 and $40 \%$ in tropical and subtropical countries, but can reach up to $70 \%$ in HIV-positive patients co-infections. It is important to mention that this parasitic disease can be more severe and even attain high mortality rates in immunocompromised patients (Barros and Montes, 2014; 
Mejia and Nutman, 2012). The Baermann-Moraes technique (specific for S. stercoralis) was not used in this study due to the use of MIF in collecting bottles distributed among patients, which prevents larva thermo-hydrotropism. MIF addition was necessary since it took the patients a few days until the next visit and fecal material delivery.

The presence of dogs and/or cats as risk factors in parasite infection was observed in this study. Although there is controversy regarding the sharing of parasitic infections between healthy domestic animals and humans, patients with severe immunodeficiency and malnourished children may be affected by opportunistic parasitic diseases, such as those caused by Cryptosporidium spp. (Curi et al., 2016; Bowman and Lucio-Forster, 2010). Even though there have been studies defining giardiasis as a zoonosis (Feng and Xiao, 2011), the genotype and subtype level division has reduced scientific acceptance of zoonotic transmission likelihood. Thus, further studies on G. lamblia and Cryptosporidium spp. molecular characterization are necessary, once the role of dogs and cats as potential zoonotic parasite sources cannot be definitely excluded and antiparasitic treatment of these pets should be regularly performed (Ballweber et al., 2010; Joffe et al., 2011).

\section{Conclusion}

With considerable enteroparasitosis levels among cancer patients, probably due to their immunocompromised condition, these individuals are at higher risk of acquiring infection by different parasitic species. Based on the results obtained in this study, fecal parasite examination and the use of specific methods for intestinal protozoa diagnosis before and during treatment of cancer patients, as well as specific treatments of positive patients for some parasitic infections so as to prevent more severe conditions that could entail potential complications for these patients, are suggested.

\section{Acknowledgements}

We would like to thank the patients who participated in the research as well as the oncology clinic professionals for their support.

\section{References}

ALEMU, A., SHIFERAW, Y., GETNET, G., YALEW, A. and ADDIS, Z., 2011. Opportunistic and other intestinal parasites among HIV/AIDS patients attending Gambi higher clinic in Bahir Dar city, North West Ethiopia. Asian Pacific Journal of Tropical Medicine, vol. 4, no. 8, pp. 661-665. PMid:21914548. http://dx.doi.org/10.1016/S1995-7645(11)60168-5.

AL-MEGRIN, W.A., 2010. Intestinal parasites infection among immunocompromised patients in Riyadh, Saudi Arabia. Pakistan Journal of Biological Sciences, vol. 13, no. 8, pp. 390-394. PMid:20836300. http://dx.doi.org/10.3923/pjbs.2010.390.394.

AMANCIO, F.A.M., PASCOTTO, V.M., SOUZA, L.R., CALVI, S.A. and PEREIRA, P.C.M., 2012. Intestinal parasitic infections in HIV/AIDS patients. The Journal of Venomous Animals and
Toxins Including Tropical Diseases, vol. 18, no. 2, pp. 225-235. http://dx.doi.org/10.1590/S1678-91992012000200013.

ASSIS, D.C., RESENDE, D.V., CABRINE-SANTOS, M., CORREIA, D. and OLIVEIRA-SILVA, M.B., 2013. Prevalence and genetic characterization of Cryptosporidium spp. and Cystoisospora belli in HIV-infected patients. Revista do Instituto de Medicina Tropical de Sao Paulo, vol. 55, no. 3, pp. 149-154. PMid:23740020. http://dx.doi.org/10.1590/S003646652013000300002 .

BALLWEBER, L.R., XIAO, L., BOWMAN, D.D., KAHN, G. and CAMA, V.A., 2010. Giardiasis in dogs and cats: update on epidemiology and public health significance. Trends in Parasitology, vol. 26, no. 4, pp. 180-189. PMid:20202906. http:// dx.doi.org/10.1016/j.pt.2010.02.005.

BARROS, N. and MONTES, M., 2014. Infection and Hyperinfection with Strongyloides stercoralis: Clinical Presentation, Etiology of Disease, and Treatment Options. Current Tropical Medicine Reports, vol. 1, no. 4, pp. 223-228. http://dx.doi.org/10.1007/ s40475-014-0030-y.

BENAMROUZ, S., CONSEIL, V., CHABÉ, M., PRAET, M., AUDEBERT, C., BLERVAQUE, R., GUYOT, K., GAZZOLA, S., MOURAY, A., CHASSAT, T., DELAIRE, B., GOETINCK, N., GANTOIS, N., OSMAN, M., SLOMIANNY, C., DEHENNAUT, V., LEFEBVRE, T., VISCOGLIOSI, E., CUVELIER, C., DEICAS, E., CREUSY, C. and CERTAD, G., 2014. Cryptosporidium parvum-induced ileo-caecal adenocarcinoma and Wnt signaling in a mouse model. Disease Models \& Mechanisms, vol. 7, no. 6, pp. 693-700. PMid:24652769. http://dx.doi.org/10.1242/dmm.013292.

BOWMAN, D.D. and LUCIO-FORSTER, A., 2010. Cryptosporidiosis and giardiasis in dogs and cats: veterinary and public health importance. Experimental Parasitology, vol. 124, no. 1, pp. 121-127. PMid:19545532. http://dx.doi.org/10.1016/j. exppara.2009.01.003.

BRUM, J.W.A., CONCEIÇÃO, A.S., GONÇALVES, F.V.C., MAXIMIANO, L.H.S., DINIZ, L.B.M.P.V., PEREIRA, M.N. and SILVA, E.S., 2013. Parasitoses oportunistas em pacientes com o vírus da imunodeficiência humana. Revista da Sociedade Brasileira de Clínica Médica, vol. 11, no. 3, pp. 280-288.

COTTON, J.A., BEATTY, J.K. and BURET, A.G., 2011. Host parasite interactions and pathophysiology in Giardia infections. International Journal for Parasitology, vol. 41, no. 9, pp. 925-933. PMid:21683702. http://dx.doi.org/10.1016/j.ijpara.2011.05.002.

CURI, N.H.A., PASCHOAL, A.M.O., MASSARA, R.L., SANTOS, H.A., GUIMARÃES, M.P., PASSAMANI, M. and CHIARELLO, A.G., 2016. Risk factors for gastrointestinal parasite infections of dogs living around protected areas of the Atlantic Forest: implications for human and wildlife health. Brazilian Journal of Biology $=$ Revista Brasileira de Biologia, vol. 77 , no. 2 , pp. 388-395.

FENG, Y. and XIAO, L., 2011. Zoonotic potential and molecular epidemiology of Giardia species and giardiasis. Clinical Microbiology Reviews, vol. 24, no. 1, pp. 110-140. PMid:21233509. http:// dx.doi.org/10.1128/CMR.00033-10.

FERREIRA, F.S., BAPTISTA-FERNANDES, T., OLIVEIRA, D., RODRIGUES, R., NEVES, E., LIMA, A., GARRIDO, E., AFONSO, G., ZAKY, A., FREITAS, P. T, ATOUGUIA, J. and CENTENO-LIMA, S., 2015. Giardia duodenalis and soil-transmitted helminths infections in children in São Tomé and Príncipe: do we think Giardia when addressing parasite 
control? Journal of Tropical Pediatrics, vol. 61, no. 2, pp. 106112. PMid:25604490. http://dx.doi.org/10.1093/tropej/fmu078.

INSTITUTO NACIONAL DE CÂNCER JOSÉ ALENCAR GOMES DA SILVA - INCA, 2016 [viewed 8 December 2016]. Estimativa 2014: Incidência de Câncer no Brasil [online]. Rio de Janeiro: INCA. Available from: http://www.inca.gov.br

JOFFE, D., VAN NIEKERK, D., GAGNÉ, F., GILLEARD, J., KUTZ, S. and LOBINGIER, R., 2011. The prevalence of intestinal parasites in dogs and cats in Calgary, Alberta. The Canadian Veterinary Journal $=$ La revue Vétérinaire Canadienne, vol. 52, no. 12, pp. 1323-1328. PMid:22654137.

KARADAG, G., TAMER, G.S. and DERVISOGLU, E., 2013. Investigation of intestinal parasites in dialysis patients. Saudi Medical Journal, vol. 34, no. 7, pp. 714-718. PMid:23860891.

LAU, S.K., WOO, P.C., WONG, S.S., MA, E.S. and YUEN, K.Y., 2007. Ascaris-induced eosinophilic pneumonitis in HIV infect patients. Journal of Clinical Pathology, vol. 60, no. 2, pp. 202-203. PMid:17264245.

LUSTIGMAN, S., PRICHARD, R.K., GAZZINELLI, A., GRANT, W.N., BOATIN, B.A., MCCARTHY, J.S. and BASÁÑEZ, M.G., 2012. A research agenda for helminth diseases of humans: The problem of helminthiases. PLoS Neglected Tropical Diseases, vol. 6, no. 4, pp. e1582. PMid:22545164. http://dx.doi.org/10.1371/ journal.pntd.0001582.

MARCOS, L.A. and GOTUZZO, E., 2013. Intestinal protozoan infections in the immunocompromised host. Current Opinion in Infectious Diseases, vol. 26, no. 4, pp. 295-301. PMid:23806893.

MEJIA, R. and NUTMAN, T.B., 2012. Screening, prevention, and treatment for hyperinfection syndrome and disseminated infections caused by Strongyloides stercoralis. Current Opinion in Infectious Diseases, vol. 25, no. 4, pp. 458-463. PMid:22691685. http://dx.doi.org/10.1097/QCO.0b013e3283551dbd.

MOURA, M.Q., JESKE, S., VIEIRA, J.N., CORRÊA, T.G., BERNE, M.E. and VILLELA, M.M., 2013. Frequency of geohelminths in public squares in Pelotas, RS, Brazil. Revista Brasileira de Parasitologia Veterinária, vol. 22, no. 1, pp. 175-178. PMid:24252968. http://dx.doi.org/10.1590/S198429612013000100034

OLIVEIRA, G., 2014. Cancer and parasitic infections: similarities and opportunities for the development of new control tools. Revista da Sociedade Brasileira de Medicina Tropical, vol. 47, no. 1, pp. 1-2. PMid:24603730. http://dx.doi.org/10.1590/00378682-0013-2014.
PACHECO, F.T.F., SILVA, R.K.N.R., MENDES, A.V.A., MENDONÇA, N., RIBEIRO, T.C.M., SOARES, N.M. and TEIXEIRA, M.C.A., 2014. Infecção por Giardia duodenalis e outros enteroparasitos em crianças com câncer e crianças de creche em Salvador, Bahia. Journal of Medical and Biological Sciencies $=$ Revista de Ciências Médicas e Biológicas, vol. 13, no. 3, pp. 280-286.

RAJA, K., ABBAS, Z., HASSAN, S.M., LUCK, N.H., AZIZ, T. and MUBARAK, M., 2014. Prevalence of cryptosporidiosis in renal transplant recipients presenting with acute diarrhea at a single center in Pakistan. Journal of Nephropathology, vol. 3, no. 4, pp. 127-131. PMid:25374881.

RESIERE, D., VANTELON, J.M., BOUREÉ, P., CHACHATY, E., NITENBERG, G. and BLOT, F., 2003. Isospora belli infection in a patient with non-Hodgkin's lymphoma. Clinical Microbiology and Infection, vol. 9, no. 10, pp. 1065-1067. PMid:14616755. http://dx.doi.org/10.1046/j.1469-0691.2003.00742.x.

SILVA, L.P., SILVA, R.M.G., FERNANDES, N.A. and OLIVEIRA, J.A.A., 2011. Parasitos e/ou comensais em pacientes neoplásicos submetidos à quimioterapia. Bioscience Journal, vol. 27, no. 1 , pp. 170-177.

TORRES-ROMERO, J.C., EUAN-CANTO, A.J., BENITOGONZÁlEZ, N., PADILLA-MONTAÑO, N., HUCHINCHAN, C., LARA-RIEGOS, J. and CEDILLO-RIVERA, R., 2014. Intestinal parasites and genotyping of Giardia duodenalis in children: first report of genotype B in isolates from human clinical samples in Mexico. Memorias do Instituto Oswaldo Cruz, vol. 109, no. 3, pp. 388-390. PMid:24676655. http://dx.doi. org/10.1590/0074-0276140507.

TOWNSEND, J.L. and CAVUOTI, D., 2015. A 32-year-old man with HIV and chronic diarrhea. Clinical Infectious Diseases, vol. 60, no. 5, pp. 821-822. PMid:25688141. http://dx.doi.org/10.1093/ $\mathrm{cid} / \mathrm{ciu} 930$

UTZINGER, J., BECKER, S.L., KNOPP, S., BLUM, J., NEUMAYR, A.L., KEISER, J. and HATZ, C.F., 2012. Neglected tropical diseases: diagnosis, clinical management, treatment and control. Swiss Medical Weekly, vol. 142, pp. w13727. PMid:23180107

VENTO, S. and CAINELLI, F., 2003. Infections in patients with cancer undergoing chemotherapy: etiology, prevention, and treatment. The Lancet Oncology, vol. 4, no. 10, pp. 595-604. PMid:14554236. http://dx.doi.org/10.1016/S1470-2045(03)01218-X. 